\title{
Spatial behaviour of soil moisture in the root zone of the Caatinga biome $^{1}$
}

\section{Comportamento espacial da umidade do solo na zona das raízes do Bioma Caatinga}

\author{
Carlos Alexandre Gomes Costa ${ }^{2 *}$, José Wellington Batista Lopes ${ }^{3}$, Everton Alves Rodrigues Pinheiro ${ }^{3}$, José \\ Carlos de Araújo ${ }^{4}$ e Raimundo Rodrigues Gomes Filho
}

\begin{abstract}
The purpose of this study was to represent the soil moisture in the profile corresponding to the root zone from TDR sensors in a preserved area of the Caatinga biome and analyze the spatialized moisture adjustment equations under different layers of the soil profile. For that, we analyzed three classes of soil (red yellow Ultisol; Hypochromic Luvisol; Udorthent) in the Aiuaba Experimental Watershed, located in the semiarid zone of northeastern Brazil. The hydro-physical parameters representing the soil water retention (field capacity, wilting point and residual moisture) were collected in four campaigns, in six points and in the profiles corresponding to the effective root depth, totaling 216 samples. For the evaluation of the regression models, we used the coefficient of determination, the Pearson correlation and the performance index. The results indicate that the analyzed parameters are homogeneous for the studied soil profiles. The Pearson correlation coefficient indicates a moderate performance for all regression equations. However, the confidence index was determined as very bad for the Red-Yellow Ultisol, passable for the Hypochromic Luvisol and bad for the Udorthent, for the rainy season, and very bad for all classes, for the dry season. Therefore, the use of the regression models is more indicated for periods of higher soil moisture.
\end{abstract}

Key words: Caatinga. Soil. Time domain reflectometry.

\begin{abstract}
RESUMO - O objetivo deste trabalho foi representar a umidade do solo no perfil correspondente à zona das raízes a partir de sensores TDR em uma área preservada do Bioma Caatinga e analisar as equações de ajuste de umidade espacializadas sob diferentes camadas do perfil do solo. Para isso, foram analisadas três classes de solo (Argissolo Vermelho-Amarelo; Luvissolo Hipocrômico; Neossolo Litólico) presentes na Bacia Experimental de Aiuaba, Semiárido do Nordeste do Brasil. Os parâmetros físico-hídricos que representam as faixas limítrofes de retenção da água no solo (capacidade de campo, ponto de murcha permanente e umidade residual) foram coletados em quatro campanhas, em seis pontos e nos perfis correspondentes à profundidade efetiva das raízes totalizando 216 amostras analisadas. Para avaliação dos modelos de regressão utilizaram-se o coeficiente de determinação, a escala de Pearson e o índice de desempenho. Os resultados indicam que os parâmetros analisados são homogêneos para os perfis de solo estudados. O coeficiente de correlação de Pearson indica desempenho moderado para as equações de ajuste. Entretanto, o índice de confiança do modelo de regressão linear foi enquadrado como péssimo para o Argissolo Vermelho-Amarelo, sofrível para o Luvissolo Hipocrômico e mau para o Neossolo Litólico para os dados do mês chuvoso, e péssimo para todas as classes no período seco. Os usos dos modelos de regressão são mais recomendados para os períodos de maior umidade do solo.
\end{abstract}

Palavras-chave: Caatinga. Solos. Reflectometria no domínio do tempo.

\footnotetext{
* Autor para correspondência

'Recebido para publicação em 10/05/2012; aprovado em 24/06/2013

Parte da Tese de Doutorado apresentada no Departamento de Engenharia Agrícola da Universidade Federal do Ceará-UFC, Brasil

${ }^{2}$ Universidade Federal de Goiás, Campus Jataí, Rodovia BR 364, Km 192, n. 3800, Parque Industrial, Jataí-GO, Brasil, costacag@gmail.com, rrgomesfilho@hotmail.com

32Departamento de Engenharia Agrícola/UFC, Campus do Pici, Bloco 804, Fortaleza-CE, Brasil, 60.451-070, wellingtonjwl@gmail.com, evertonvest@yahoo.com.br

${ }^{4}$ Departamento de Engenharia Agrícola/UFC, Centro de Ciências Agrárias, Fortaleza-CE, Brasil, jcaraujo@ufc.br
} 


\section{INTRODUCTION}

Water in the soil plays an important role in regulating the water cycle. Its distribution is the main object of study in investigations into the water balance of the different layers present in a soil profile (CRUZ et al., 2005; PARAJKA et al., 2006; PENNA et al., 2009). However, one of the biggest challenges facing these investigations relates to estimating the soil water content, since in the field there is significant variability of both space and time (GAO et al., 2011; TIMM et al., 2011), mainly arising from the variability of both the physical and water characteristics of the soil (CAJAZEIRA; ASSIS JUNIOR, 2011). To this end, the spatial variability of these properties must be well known in order to minimize errors when taking samples and in soil management (GREGO; VIEIRA, 2005; SOUZA et al., 2004). The soil displays both vertical and horizontal heterogeneity, imposed by the nature of those factors responsible for its formation. Accordingly, autoregressive models applied in the study of this variability, give an understanding of the processes of the interactions in a soil-plant-atmosphere system (TIMM et al., 2003).

In such a system, the vegetation also considerably affects the variation of moisture in a soil profile (SANTOS; SILVA; MONTENEGRO, 2010). Burgess et al. (1998) show that the root system transfers water between the soil layers, working as a hydraulic lift, that is, the flow of water is from the wetter to the drier layers, suggesting that this rise significantly affects the distribution and availability of water in the different layers of soil. Thus Brocca et al. (2012) argue that the different layers within the soil profile are characterized by distinct hydrological behavior. Therefore analyses which take into account the entire soil profile are justified when reaching more general conclusions about the pattern of moisture distribution in the root zone.

For Medeiros, Araujo and Bronstert (2009), an understanding of the hydrological processes is of fundamental importance in quantifying water availability in all major areas, including the soil, as well as estimating sediment yield (LIMA NETO; WIEGAND; ARAÚJO, 2011; MEDEIROS et al., 2010). For Carvalho et al. (2002) soil depth is important in the analysis of the spatial variability of the soil. However, according to Penna et al. (2009) and Bolten et al. (2010), the monitoring techniques that represent the spatial and temporal variability of soil moisture at the profile level, can be readily applied in hydrological modeling, and are necessary for a better understanding of the hydrological processes.

The monitoring of soil moisture however, considers spot samples which are limited to a few square metres and are not commonly used, so the use of alternatives such as TDR (or Time Domain Reflectometry) humidity sensors (EVETT et al., 2012; GAO et al., 2011; LI et al., 2004) optimise measurements of soil water content both over time and space (PENNA et al., 2009; QUINONES; RUELLE, 2001; MAILAPALLI et al., 2008; SANTOS; SILVA; MONTENEGRO, 2010). Despite the gain in temporal resolution, each TDR monitors a single layer of soil, usually the most superficial (BONI et al., 2008; MIRANDA; GONDIM; COSTA, 2006).

With that in mind, the aim of this work was to represent the soil moisture in that profile which corresponds to the root zone, using TDR sensors in a preserved area of the Caatinga biome, and to analyse the spatialized moisture-adjustment equations at different layers of the soil profile.

\section{MATERIAL AND METHODS}

The study was conducted at the Aiuaba Experimental Watershed (AEW), with a total area of 12 $\mathrm{km}^{2}$, located in the Aiuaba Ecological Station, at Inhamuns, Ceará, Brazil, whose coordinates are $6^{\circ} 42^{\prime} \mathrm{S}$ and $40^{\circ} 17^{\prime}$ $\mathrm{W}$ (Figure 1). The climate is type ' $\mathrm{BS}$ ' according to the Köppen classification, with an average annual rainfall of $560 \mathrm{~mm}$, an average air temperature of around $27^{\circ} \mathrm{C}$ and a relative humidity of around $56 \%$. The watershed has a mean gradient of $19 \%$, and its geology is made up of crystalline complex and sedimentary formation. The AEW is completely preserved and covered with natural Caatinga (ARAÚJO; PIEDRA, 2009).

The AEW includes three classes of soil: a RedYellow Ultisol, a Hypochromic Luvisol; a Litholic Neosol. Each class of soil has a monitoring station equipped with a TDR soil-moisture sensor installed in the 0 to $0.20 \mathrm{~m}$ layer.

The physical water parameters studied correspond to the range limits of the water moisture in the soil (field capacity moisture $-\theta_{\mathrm{FC}}$; permanent wilting point moisture - $\theta_{\mathrm{WP}}$; residual soil moisture - $\theta_{\mathrm{RES}}$ ). To determine these parameters the methodology proposed by EMPRESA BRASILEIRA DE PESQUISA AGROPECUÁRIA (1997) was adopted. Soil collection was carried out at four different periods corresponding to the soil water content (the dry, wet and transition seasons), in order better to represent moisture variations in the watershed. For each collection, six sample profiles were drilled for each class of soil in the AEW. The depth analyzed for each profile was restricted to that obtained by Pinheiro; Costa and Araújo (2013) when identifing the effective depth of the root systems of the predominant vegetation for the classes of soil analyzed (Red-Yellow Ultisol: 0.73 m; Hypochromic 
Figure 1 - Location of AEW, layers analyzed the profiles of Red-Yellow Ultisol, Hypochromic Luvisol and Litholic Neosol
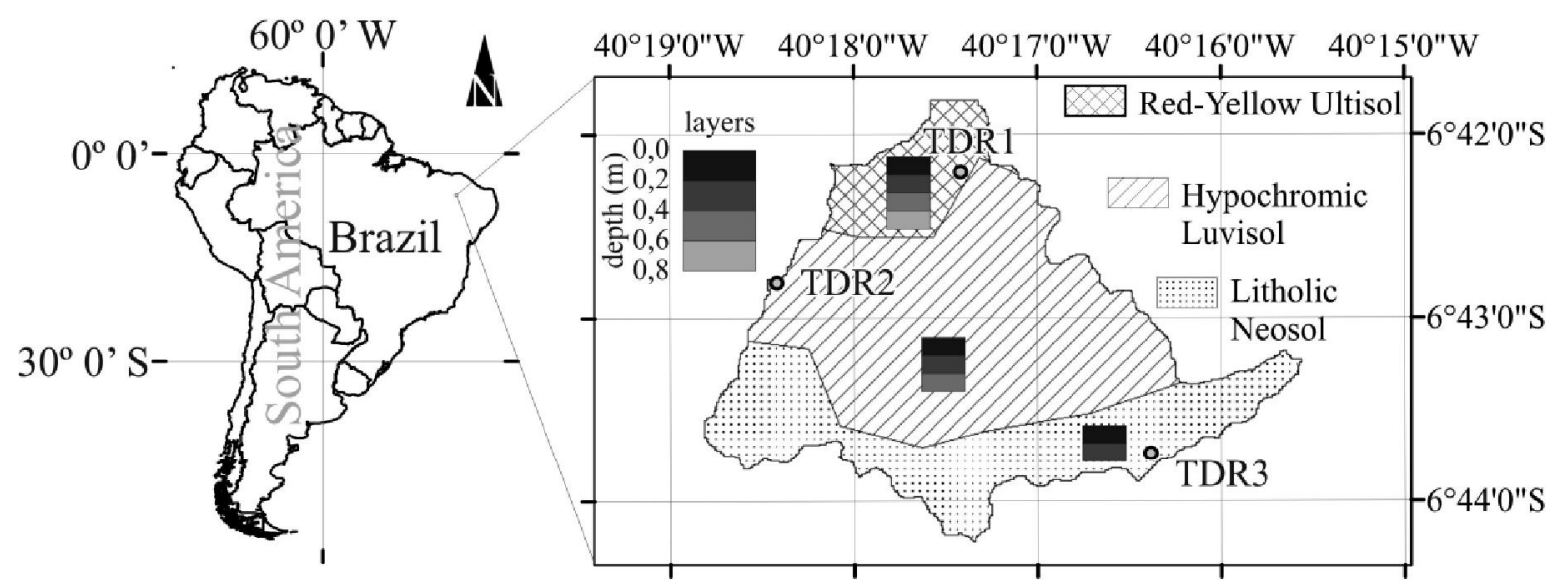

Luvisol: $0.63 \mathrm{~m}$; Litholic Neosol: $0.36 \mathrm{~m})$. Using this criterion, four, three and two layers were established, each with a thickness of $0.20 \mathrm{~m}$, for the classes of soil Red-Yellow Ultisol, Hypochromic Luvisol and Litholic Neosol respectively (Figure 1). In this way, 216 samples were collected and analyzed. Field capacity moisture data, permanent wilting point moisture data, residual moisture data and present humidity data, all obtained in the field, were subjected to variance analysis, the means being compared using the Student's t-test for independent samples, at a significance level of $1 \%$.

For this research, the spatialisation of soil moisture using autoregressive models was chosen, resulting in a curve of adjustment that relates the spot data from three monitoring stations to the spatialized samples distributed throughout all the classes of soil of the AEW.

To evaluate the performance of the equations generated by the regression analysis of the three classes of soil of the AEW, use was made of the criteria used by Rodrigues et al. (2007), and Batista et al. (2006), which were based on the following statistical indices: the coefficient of determination $\left(\mathrm{r}^{2}\right)$, which indicates the degree of correlation between the independent variables and the dependent variable, the Pearson correlation coefficient (r, see Equation 1), and the concordance index (d, see Equation 2), proposed by Willmott (1981), which indicates the degree of accuracy of the equation, and may assume values of zero for no concordance to one for perfect concordance. Finally, the confidence index of the model (c, see Equation 3) was analyzed. This joins the indications of the two coefficients, $r$ and $d$, as proposed by Camargo and Sentelhas (1997). For validation, different data to those used for calibration were employed, thereby avoiding failures caused by the auto-correlation of the data, which could lead to performance evaluation of the equations giving biased results.

$$
\begin{aligned}
& r=\frac{\sum_{i=1}^{n}\left(\theta m_{i}-\overline{\theta m}\right)\left(\theta e_{i}-\overline{\theta e}\right)}{\sqrt{\sum_{i=1}^{n}\left(\theta m_{i}-\overline{\theta m}\right)^{2}} \sqrt{\sum_{i=1}^{n}\left(\theta e_{i}-\overline{\theta e}\right)^{2}}} \\
& d=1-\frac{\sum_{i=1}^{n}\left(\theta e_{i}-\theta m_{i}\right)^{2}}{\sum_{i=1}^{n}\left(\left|\theta e_{i}-\overline{\theta m}\right|+\left|\theta m_{i}-\overline{\theta m}\right|\right)^{2}}
\end{aligned}
$$

Where: $\theta m_{i}=$ measured moisture value, $\mathrm{m}^{3} \mathrm{~m}^{-3}$; $\overline{\theta m}=$ mean of measured moisture values, $\mathrm{m}^{3} \mathrm{~m}^{-3} ; \theta e=$ modeled humidity value, $\mathrm{m}^{3} \mathrm{~m}^{-3} ; \overline{\theta e}=$ mean of modeled humidity values; $n=$ number of measurements; and $d=$ concordance index.

$c=r \times d$

Where: $\mathrm{c}=$ confidence index, $\mathrm{r}=$ Pearson correlation coefficient.

To choose the model that best represents the adjustment of soil moisture for the class of soil to spot moisture, the coefficient of determination, the Pearson correlation scale and the performance-confidence index were considered (Table 1).

For analysis of the adjustment model, two sets of hourly data taken from one month under two different water regimes, were evaluated: one in the rainy season (April, 2009) and another in the dry season (October, 2009). The year chosen (2009) had normal rainfall, according to Xavier and Xavier (1999). This criterion was adopted in order to observe the best response of these linear models under normal conditions of 
Table 1 - Scale coefficient of determination, Pearson correlation coefficient and the confidence index

\begin{tabular}{|c|c|c|c|}
\hline \multicolumn{2}{|c|}{ Pearson correlation scale } & \multicolumn{2}{|c|}{ Performance-confidence index } \\
\hline intervals & performace & intervals & performace \\
\hline $0 \leq \mathrm{r}^{2}<0.25$ & weak & $\mathrm{c} \leq 0.40$ & very bad \\
\hline $0.25 \leq \mathrm{r}^{2}<0.81$ & moderate & $0.40<\mathrm{c} \leq 0.50$ & bad \\
\hline $0.81 \leq \mathrm{r}^{2} \leq 1$ & strong & $0.50<c \leq 0.60$ & tolerable \\
\hline $0 \leq \mathrm{r}<0.50$ & weak & $0.60<\mathrm{c} \leq 0.65$ & average \\
\hline $0.50 \leq \mathrm{r}<0.90$ & moderate & $0.65<\mathrm{c} \leq 0.75$ & good \\
\hline $0.90 \leq \mathrm{r} \leq 1$ & strong & $0.75<\mathrm{c} \leq 0.85$ & very good \\
\hline- & - & $c>0.85$ & great \\
\hline
\end{tabular}

Coefficient of determination $\left(\mathrm{r}^{2}\right)$; Pearson correlation coefficient (r); confidence index (c). adapted from Camargo and Sentelhas (1997)

humidity (intra-annually variable) and conditions of preserved vegetation (ARAÚJO; PIEDRA, 2009).

\section{RESULTS AND DISCUSSION}

Table 2 shows the test results for the comparison of the averages of the studied physical and water parameters. For those variables studied, there was no statistically significant difference $(\mathrm{p}<0.001)$ between the layers in the soil profiles.

Despite the observations of Brocca et al. (2012) showing that the various layers within a soil profile are characterized by different hydrological behaviors, the results obtained in the field indicate that the limiting layers of water retention in the soil do not show significant variation in the soil profile of the root zone.
The homogeneous field capacity throughout the profile suggests a unique pattern of water retention at field-capacity tension $(-0.33 \mathrm{~atm})$, that is, from the hydrological point of view this parameter does not alter the conditions which are critical to the start of surface runoff. In a semiarid environment, excess rainfall in some areas is limited to the conditions of great-magnitude events, or after a sequence of rainfall events, suggesting a scale effect on the hydrological properties of the soil Medeiros et al. (2010).

When studying the conditions for the generation of runoff in the same watershed, AEW, dividing it into two sub-basins, Figueiredo (2011) showed that the largest runoff volumes occur in the plot with the Hypochromic Luvisol (mean field capacity of the profile of $0.225 \mathrm{~m}^{3} \mathrm{~m}^{-3}$ ), against a value of $0.280 \mathrm{~m}^{3} \mathrm{~m}^{-3}$ for field capacity for the sub-basin with a predominance of

Table 2 - Results of the Student's t-test for comparison of means for independent samples. Values represent the difference between the average moisture $\left(\mathrm{m}^{3} \cdot \mathrm{m}^{-3}\right)$ for the hydro-physical parameters analyzed distributed in the profiles of the three soil types in the AEW

\begin{tabular}{|c|c|c|c|c|c|c|c|}
\hline \multirow{2}{*}{$\begin{array}{l}\text { Hydro-physical } \\
\text { parameters }\end{array}$} & \multirow{2}{*}{$\begin{array}{l}\text { Depth } \\
\text { (m) }\end{array}$} & \multicolumn{3}{|c|}{ Red-Yellow Ultisol } & \multicolumn{2}{|c|}{ Hypochromic Luvisol } & \multirow{2}{*}{$\begin{array}{c}\text { Litholic Neosol } \\
0-0.4 \mathrm{~m}\end{array}$} \\
\hline & & $0-0.4 \mathrm{~m}$ & $0-0.6 \mathrm{~m}$ & $0-0.8 \mathrm{~m}$ & $0-0.4 \mathrm{~m}$ & $0-0.6 \mathrm{~m}$ & \\
\hline RES & & $0.0001^{\mathrm{ns}}$ & $0.0009^{\mathrm{ns}}$ & $-0.0027^{\mathrm{ns}}$ & $0.0002^{\mathrm{ns}}$ & $-0.0051^{\mathrm{ns}}$ & $-0.0022^{\mathrm{ns}}$ \\
\hline WP & $0-0.2$ & $0.0108^{\mathrm{ns}}$ & $-0.0214^{\mathrm{ns}}$ & $-0.0273^{\mathrm{ns}}$ & $-0.0120^{\mathrm{ns}}$ & $0.0035^{\mathrm{ns}}$ & $-0.0151^{\mathrm{ns}}$ \\
\hline $\mathrm{FC}$ & & $-0.0265^{\mathrm{ns}}$ & $-0.0424^{\mathrm{ns}}$ & $-0.0422^{\mathrm{ns}}$ & $-0.0089^{\mathrm{ns}}$ & $-0.0086^{\mathrm{ns}}$ & $-0.0225^{\mathrm{ns}}$ \\
\hline RES & & & $-0.0009^{\text {ns }}$ & $-0.0028^{\mathrm{ns}}$ & & $-0.0052^{\mathrm{ns}}$ & \\
\hline WP & $0-0.4$ & & $-0.0106^{\mathrm{ns}}$ & $-0.0166^{\mathrm{ns}}$ & & $0.0155^{\mathrm{ns}}$ & \\
\hline $\mathrm{FC}$ & & & $-0.0159^{\mathrm{ns}}$ & $-0.0157^{\mathrm{ns}}$ & & $0.0003^{\mathrm{ns}}$ & \\
\hline RES & & & & $-0.0019^{\mathrm{ns}}$ & & & \\
\hline WP & $0-0.6$ & & & $-0.0059^{\mathrm{ns}}$ & & & \\
\hline $\mathrm{FC}$ & & & & $0.0002^{\mathrm{ns}}$ & & & \\
\hline
\end{tabular}


a Red-Yellow Ultisol. This characterizes the capability of a Hypochromic Luvisol for producing surface runoff, and consequently for sediment production, exceeding by $24 \%$ the capacity of a Red-Yellow Ultisol in the production of surface runoff. Added to that is the fact of the greater range of the Hypochromic Luvisol on the steepest parts of the AEW. On the other hand, the Red-Yellow Ultisol is in the outflow area of the watershed and is known to show signs of sediment deposition (Medeiros et al., 2010) with the formation of layers in the soil.

In this research, we considered the permanent wilting point as being moisture below which vegetation can no longer absorb water from the soil, corresponding to the lower limit of soil-water availability. However, this concept has been discussed (BIGELOW; BOWMAN; CASSEL, 2004) when it comes to biomes with a tolerance to water stress, as notably observed in the Caatinga. Thus, it must be considered that plants have different strategies for water absorption, accordingly the values shown based on the soil are restricted to the matric potential (retention energy of around -15 atm) see for example, (CAJAZEIRA; ASSIS JUNIOR, 2011) and were so considered in the development of this work. In the profiles analyzed, the moisture at the permanent wilting point also showed no variability, just like the residual moisture which showed less variation. Thus, one can synthesize that the range of variability changes according to the water content of the soil. A lower water content corresponds to a lower variability. In Figure 2, the amplitude of the parameters for the different classes of soil can be seen. For the RedYellow Ultisol and Litholic Neosol, the largest amplitudes followed the sequence of the greatest water content retained by the soil (field capacity > wilting point > residual moisture), except for the Hypochromic Luvisol, which showed a wider variation in the water content retained for the permanent wilting point, relative to field capacity. This probably occurred because there is a greater amount of clay in this type of soil (Table 3). From the standpoint of texture, it is known that the higher the clay content of the soil, the higher the water content for a given matric potential (VAN LIER; DOURADO NETO,
METSELAAR, 2009). According Cajazeira and Assis Junior (2011), this fact is due to the nature of colloidal material, which has greater surface area per unit mass than coarser materials (sand and silt, for example).

Figure 2 - Range limits and distribution of the data of soil moisture for the profiles of three class of soil existing at the AEW: $\theta_{\mathrm{RES}}$ (residual moisture); $\theta_{\mathrm{WP}}$ (wilting point); $\theta_{\mathrm{FC}}$ (field capacity)

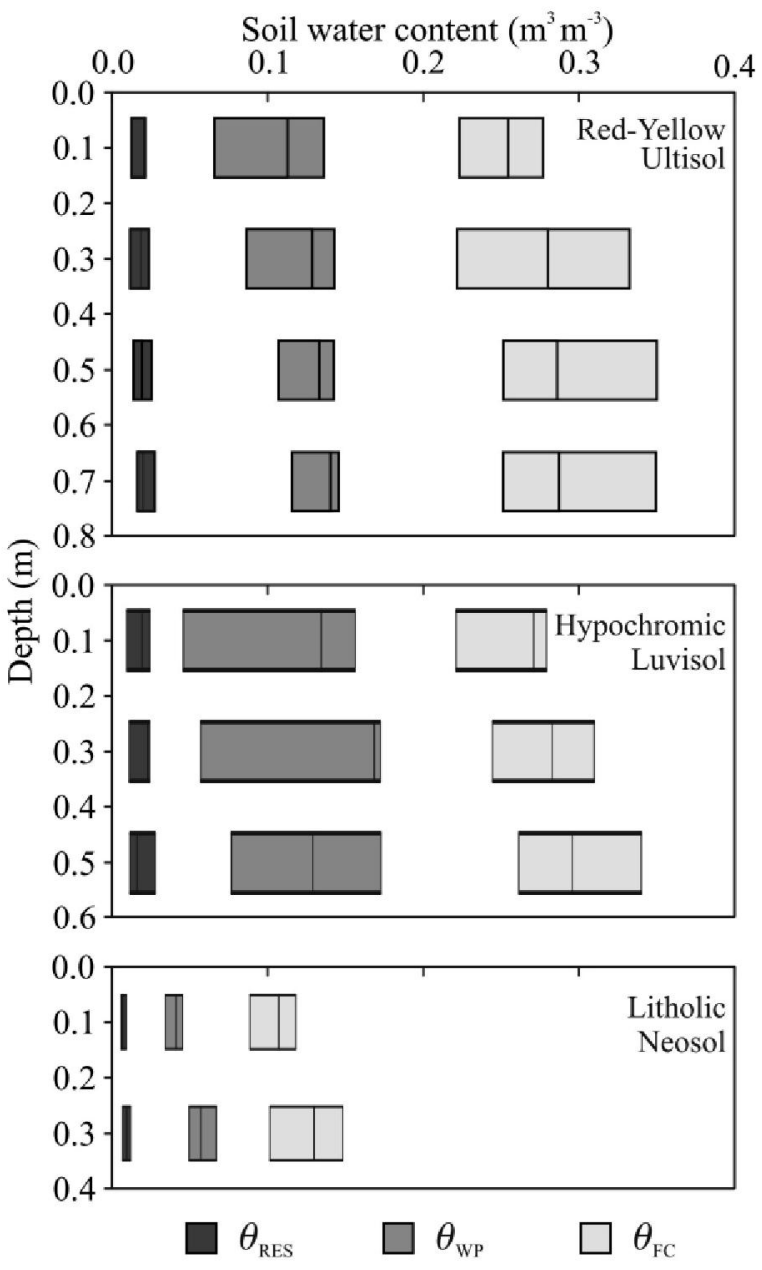

Table 3 - Particle size, dry-bulk density of soil $\left(\rho_{\text {solo }}\right)$, real specific bulk $\left(\rho_{\text {part }}\right)$, soil porosity $(\alpha)$ and textural classes of the three classes of soil studied at the AEW

\begin{tabular}{|c|c|c|c|c|c|c|c|}
\hline \multirow{2}{*}{ Soil } & Sand & Silt & Clay & $\rho_{\text {soil }}$ & $\rho_{\text {part }}$ & $\alpha$ & Textural Classes \\
\hline & \multicolumn{3}{|c|}{ - } & \multicolumn{2}{|c|}{ 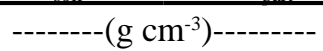 } & $(\%)$ & \\
\hline ULT & 35 & 54 & 11 & 1.44 & 2.56 & 43.70 & silt loam \\
\hline LUV & 31 & 48 & 21 & 1.21 & 2.58 & 52.87 & loam \\
\hline NEO & 61 & 35 & 4 & 1.47 & 2.52 & 41.40 & sandy loam \\
\hline
\end{tabular}

ULT: Red-Yellow Ultisol; LUV: Hypochromic Luvisol; NEO: Litholic Neosol 
The summary of the variance analysis for the representativeness of the soil moisture can be seen in Table 4. It can be observed that the depth and type of soil caused significant changes $(\mathrm{P}<0.01)$ in the variable of soil moisture. Nevertheless, it is noteworthy that variance analysis is not a prerequisite for further analyses, in accordance with Chew, (1976). The highest coefficients of variation were observed for the RedYellow Ultisol while the lowest variability was seen for the Litholic Neosol. This is due to the actual mineralogy and the creation of the soil. While the Litholic Neosol loses the most superficial layers by erosion, the RedYellow Ultisol is characterized by layers formed through sediment deposition (MEDEIROS et al., 2010).
The regression analysis is shown in Table 5 . There was a good response to the linear regression between the moisture measured continuously by TDR and the average moisture in the soil for all those classes of soil and depths evaluated. The coefficient of determination decreases with the increasing soil depth, a decrease can be seen in the representativeness of the spot measurements at the deeper layers. The lowest values of $\mathrm{r}^{2}$ in the layers of 0 to $0.2 \mathrm{~m}$ and 0 to $0.4 \mathrm{~m}$ were seen in the Litholic Neosol, mainly because of its being a shallow soil with rocky outcrops and a high potential for sediment production (LIMA NETO; WIEGAND; ARAÚJO, 2011). Nevertheless, the values of $r^{2}$ are better than those obtained by Penna et al. (2009). The

Table 4 - Summary of the analysis of variance of representativeness of the soil moisture at the monitoring station in relation to spatialisation of the three class of soil at the AEW

\begin{tabular}{lcccccccc}
\hline \multicolumn{2}{l}{ Classes and soil depth } & D.F. Model & D.F. Error & M.S. Model & A.S. Error & F & Prob & CV (\%) \\
\hline \multirow{3}{*}{ Red-Yellow } & $0-0.2 \mathrm{~m}$ & 1 & 23 & 0.066 & 0.0011 & 60.224 & 0.001 & 45.5 \\
Ultisol & $0-0.4 \mathrm{~m}$ & 1 & 23 & 0.041 & 0.0012 & 34.973 & 0.001 & 39.8 \\
& $0-0.6 \mathrm{~m}$ & 1 & 23 & 0.025 & 0.0013 & 19.618 & 0.001 & 36.9 \\
& $0-0.8 \mathrm{~m}$ & 1 & 23 & 0.024 & 0.0009 & 27.158 & 0.001 & 34.4 \\
\hline \multirow{2}{*}{ Hypochromic } & $0-0.2 \mathrm{~m}$ & 1 & 23 & 0.043 & 0.0009 & 47.301 & 0.001 & 43.2 \\
Luvisol & $0-0.4 \mathrm{~m}$ & 1 & 23 & 0.032 & 0.0009 & 37.498 & 0.001 & 39.5 \\
& $0-0.6 \mathrm{~m}$ & 1 & 23 & 0.027 & 0.0009 & 31.390 & 0.001 & 40.9 \\
\hline Litholic & $0-0.2 \mathrm{~m}$ & 1 & 23 & 0.019 & 0.0005 & 36.579 & 0.001 & 32.2 \\
Neosol & $0-0.4 \mathrm{~m}$ & 1 & 23 & 0.017 & 0.0005 & 33.000 & 0.001 & 31.3 \\
\hline
\end{tabular}

${ }^{1}$ Degree of freedom (D.F); Mean square (A.S); calculated F (F); Significance (Signif.); Coefficient of variation (CV)

Table 5 - Regression analysis of representativeness of the soil moisture at the monitoring station versus soil moisture in the three classes of soil existing at the AEW and in several dephts

\begin{tabular}{|c|c|c|c|}
\hline $\mathrm{Y}(\mathrm{m})$ & Code & Equation & $\mathrm{r}^{2}$ \\
\hline \multicolumn{4}{|c|}{ Red-Yellow Ultisol } \\
\hline $0-0.2$ & A20 & $\theta_{0-0.2}=-0.189+\left(1.102 * \theta_{\mathrm{TDR} 1}\right)$ & 0.801 \\
\hline $0-0.4$ & $\mathrm{~A} 40$ & $\theta_{0-0.4}=-0.123+\left(0.863 * \theta_{\mathrm{TDR} 1}\right)$ & 0.702 \\
\hline $0-0.6$ & A60 & $\theta_{0-0.6}=-0.0782+\left(0.695 * \theta_{\text {TDR1 }}\right)$ & 0.595 \\
\hline $0-0.8$ & A80 & $\theta_{0-0.8}=-0.0595+\left(0.619 * \theta_{\mathrm{TDR} 1}\right)$ & 0.553 \\
\hline \multicolumn{4}{|c|}{ Hypochromic Luvisol } \\
\hline $0-0.2$ & $\mathrm{~L} 20$ & $\theta_{0-0.2}=-0.0736+\left(1.341 * \theta_{\mathrm{TDR} 2}\right)$ & 0.674 \\
\hline $0-0.4$ & L40 & $\theta_{0-0.4}=-0.0527+\left(1.192 * \theta_{\mathrm{TDR} 2}\right)$ & 0.640 \\
\hline $0-0.6$ & $\mathrm{~L} 60$ & $\theta_{0-0.6}=-0.0494+\left(1.162 * \theta_{\mathrm{TDR} 2}\right)$ & 0.587 \\
\hline \multicolumn{4}{|c|}{ Litholic Neosol } \\
\hline $0-0.2$ & $\mathrm{~N} 20$ & $\theta_{0-0.2}=-0.0166+\left(0.903 * \theta_{\mathrm{TDR} 3}\right)$ & 0.624 \\
\hline $0-0.4$ & $\mathrm{~N} 40$ & $\theta_{0-04}=-0.0103+\left(0.849 * \theta_{\mathrm{TDR} 3}\right)$ & 0.600 \\
\hline
\end{tabular}

Layer of profile $(\mathrm{Y})$; Coefficient of determination $\left(\mathrm{r}^{2}\right) ; \theta_{\mathrm{TDR}}$ soil moisture $\left(\mathrm{m}^{3} \mathrm{~m}^{-3}\right)$ in the monitoring station got from TDR sensors 
greatest variability in the coefficient of determination for the Red-Yellow Ultisol, is mainly due to the heterogeneity with which the layers settle over time in this area of the watershed. Although the values for CV (between $30 \%$ and $45 \%$ ) are apparently high, Warrick and Nielsen (1980); Silva et al. (2003); Lanzanova et al. (2007); Cajazeira and Assis Junior (2011) consider them as being values of average variability for the physical and water parameters of the soil. According to these authors, there is a high spatial variability related to those physical attributes that are related to the dynamics of the water in the soil. The same authors consider values for the coefficient of variation of between $12 \%$ and $60 \%$ as average variability, and values below and above this range as low and high variability respectively.

Penna et al. (2009) developed a similar study in the Italian Alps (northern Italy), in the steeper areas of an experimental basin of $2 \mathrm{~km}^{2}$ with an alpine climate and annual rainfall around $1,200 \mathrm{~mm}$, of which approximately $50 \%$ is in the form of snow. The results obtained in this study indicate that the linear model in the 0 to $0.2 \mathrm{~m}$ layer also displays the highest coefficients of determination, like those obtained by the authors mentioned above. As a soil profile is analyzed at greater depth, the coefficient of determination reduces considerably. The aforementioned authors also observed a marked effect from the dew on the uppermost layer $(0-0.06 \mathrm{~m})$. Thus it can be seen that as the water content of the soil in the profile decreases, so too the representativeness of the spot sample for the soil decreases.

According to Santos, Silva and Montenegro (2010), in the Brazilian semiarid region, the surface conditions significantly influence the variation of the soil water content in both the dry and wet seasons. This source of variation was not seen for the classes of soil as a function of the state of preservation of the vegetation in the AEW. The temporal distribution of soil water content was carried out for two months, in the wet period (Figure 3) and the dry period (Figure 4), namely April, 2009 and October, 2009 respectively. In Figure 3 can be seen a greater variation between the measured moisture values at the monitoring station and those values derived from the equations of linear adjustment for various depths (Table 5). Further, a small variation was also observed between the moisture curves for the Red-Yellow Ultisol at the four depths analyzed. This occurs due to the homogeneity of the soil moisture in the soil profile previously discussed. On the other hand, analysis of the Hypochromic Luvisol (Figure 3b) indicates that the values measured at the monitoring station are very close to those values set by the linear models for the three depths. This contributed to the
Figure 3 - Soil moisture distribution at the monitoring stations through the equations of fit in the respective depths of Red-Yellow Ultisol, Hypochromic Luvisol, Litholic Neosol existing at the AEW in april month, rainy season

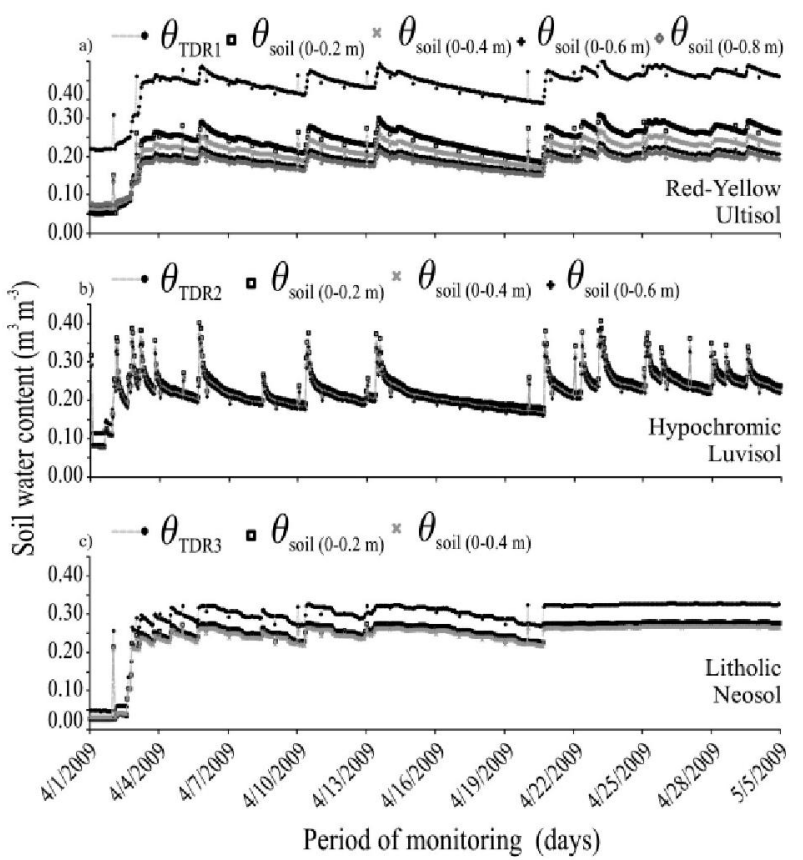

Figure 4 - Soil moisture distribution at the monitoring stations through the equations of fit at the respective depths of Red-Yellow Ultisol, Hypochromic Luvisol, Litholic Neosol existing at the AEW in october month, dry season

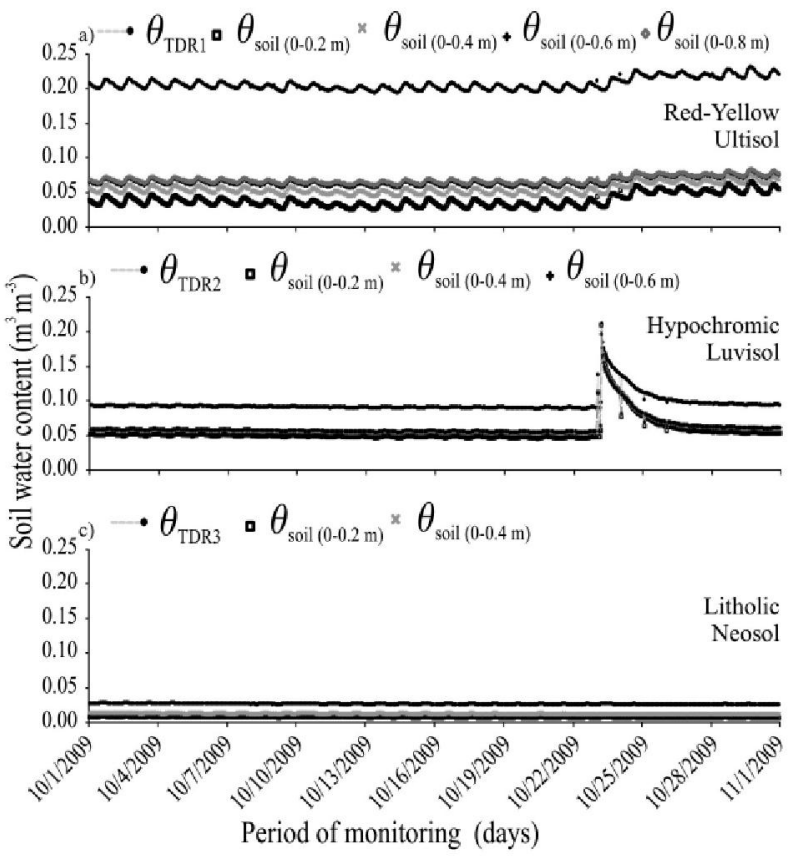


best spatially-distributed representation of moisture being obtained. The behaviour of the Litholic Neosol (Figure 3C) is characterized by having a smaller distance between the adjustment curves, the data taken in the field, and the adjusted humidity, than the RedYellow Ultisol, besides the great similarity between the adjustment equations for the two depths analyzed in this soil (Table 5). In the period of low humidity (October, 2009) (Figure 4), the behavior is similar, due to the use of the same equations. The most important observation of this graph is shown in Figure $4 \mathrm{~b}$. In the dry season, there is an abrupt change of soil moisture, showing that the behavior of the adjustment equations for the Hypochromic Luvisol are better represented in the higher humidity range, which corroborates studies by Penna et al. (2009). Moreover, the behavior for this class of soil, which was similar in the wet season, is more scattered in the dry season, with a clear separation between the curves of the analyzed profiles.

The analysis of the spatial and temporal distribution of the water content of the soil in the dry and wet seasons observed by Gao et al. (2011) showed a better analysis of soil moisture than a joint analysis of the water regimes. This happens due to the high variability of this parameter during the rainy season in the semiarid region of the Loess Plateau in China.

Table 6 presents the summary of the analysis of the Pearson correlation coefficient (r), the concordance index (d) and the confidence index (c) for the regression equations generated for the classes and depth of the soil profiles.

It is observed that the Pearson correlation coefficient indicates a moderate performance $(0.5<$ $\mathrm{r}<0.9)$ for all equations. However, the confidence index was characterized as extremely bad $(c<0.4)$ for the Red-Yellow Ultisol, tolerable $(0.5<\mathrm{c}<0.6)$ for the Hypochromic Luvisol and bad $(0.4<\mathrm{c}<0.55)$ for the Litholic Neosol for data from the rainy month and as extremely bad $(c<0.4)$ for all classes in the dry season. This indicates a greater distance between the spot metering of the TDR relative to the plot of land in the dry season compared to the wet season. It also indicates that the soil, as a reservoir, presents greater homogeneity the closer it is to the saturation point.

Table 6 - Analysis of Pearson correlation coefficient (r), concordance index (d) and confidence index (c) for the regression equations generated for the classes and depth of the soil profiles at the AEW

\begin{tabular}{|c|c|c|c|c|c|c|c|}
\hline \multirow{2}{*}{ Soil class } & \multirow{2}{*}{$\begin{array}{l}\text { Equation } \\
\text { code }\end{array}$} & \multirow{2}{*}{$\begin{array}{l}\text { Layer depth } \\
\quad(\mathrm{m})\end{array}$} & \multirow{2}{*}{$\mathrm{r}$} & \multicolumn{2}{|c|}{ April (2009) } & \multicolumn{2}{|c|}{ October (2009) } \\
\hline & & & & $\mathrm{d}$ & $\mathrm{c}$ & $\mathrm{d}$ & c \\
\hline \multirow{4}{*}{ Red-Yellow Ultisol } & A20 & $0-0.2$ & 0.89 & 0.44 & 0.39 & 0.08 & 0.07 \\
\hline & $\mathrm{A} 40$ & $0-0.4$ & 0.84 & 0.36 & 0.30 & 0.09 & 0.07 \\
\hline & A60 & $0-0.6$ & 0.77 & 0.31 & 0.24 & 0.09 & 0.07 \\
\hline & A 80 & $0-0.8$ & 0.74 & 0.29 & 0.21 & 0.09 & 0.07 \\
\hline \multirow{3}{*}{ Hypochromic Luvisol } & L20 & $0-0.2$ & 0,82 & 0.71 & 0.58 & 0.37 & 0.30 \\
\hline & L40 & $0-0.4$ & 0,80 & 0.75 & 0.60 & 0.42 & 0.34 \\
\hline & L60 & $0-0.6$ & 0.77 & 0.76 & 0.58 & 0.42 & 0.32 \\
\hline \multirow{2}{*}{ Litholic Neosol } & $\mathrm{N} 20$ & $0-0.2$ & 0.79 & 0.59 & 0.47 & 0.05 & 0.04 \\
\hline & $\mathrm{N} 40$ & $0-0.4$ & 0.77 & 0.64 & 0.50 & 0.07 & 0.06 \\
\hline
\end{tabular}




\section{CONCLUSION}

Analyses of the physical and water parameters that represented the limiting bands of moisture in those soils studied at the Aiuaba Experimental Waterbasin, lead to the conclusion that the profiles are homogeneous for the region of influence of the roots of the preserved Caatinga. They also allow the conclusion that curve fitting of the soil moisture presents better results in the rainy season than in the dry season.

\section{ACKNOWLEDGEMENTS}

The authors wish to thank the Federal University of Goiás, Jataí Campus, profesor Edésio Fialho dos Reis, PET-Agronomy at the Federal University of Ceará and CNPq (process 200672/2012-6), for their support.

\section{REFERENCES}

ARAÚJO , J. C. de; PIEDRA J. I. G. Comparative hydrology: analysis of a semiarid and a humid tropical watershed. Hydrological Processes, v. 23, n. 8, p. 1169-1178, 2009.

BATISTA, T. M. et al. Modelagem da estrutura iônica das águas da bacia hidrográfica do Acaraú, Ceará. Revista Ciência Agronômica, v. 37, n. 1, p. 1-6, 2006.

BIGELOW, C. A.; BOWMAN, D. C.; CASSEL, D. K. C. Crop Science, v. 44, n. 3, p. 900-906, 2004.

BOLTEN, J. D. et al. Evaluating the utility of remotely-sensed soil moisture retrievals for operational agricultural drought monitoring. IEEE J. Sel. Topics Applied Earth Observations, v. 3, n. 1, p. 57-66, 2010.

BONI, G. H. et al.Distribuição do sistema radicular do cajueiro-anão precoce (clone CCP-09) em cultivo irrigado e sequeiro, Ceará, Brasil. Revista Ciência Agronômica, v. 39, n. 1, p. 1-6, 2008.

BROCCA, L. et al. Catchment scale soil moisture spatialtemporal variability. Journal of hydrology, v. 422/423, p. 2012.

BURGESS, S. O. et al. The redistribution of soil water by tree root systems. Oecologia, v. 115, n. 3, p. 306-311, 1998.

CAJAZEIRA, J. P.; ASSIS JUNIOR, R. N. de. Variabilidade espacial das frações primárias e agregados de um Argissolo no Estado do Ceará. Revista Ciência Agronômica, v. 42, n. 2, p. 258-267, 2011.

CAMARGO, A. P.; SEnTElhas, P. C. Avaliação do desempenho de diferentes métodos de estimativa da evapotranspiração potencial no estado de São Paulo, Brasil. Revista Brasileira de Agrometeorologia, v. 5, n. 1, p. 8997, 1997.
CARVAlHO, J. R. P. et al. Geoestatística na determinação da variabilidade espacial de características químicas do solo sob diferentes preparos. Pesquisa Agropecuária Brasileira, v. 37, n. 8, p. 1151-1159, 2002.

CHEW, V. Comparing treatment means: a compendium. Hortscience, v. 11, n. 4, p. 348-357, 1976.

CRUZ, A. C. R. et al. Balanço de água no volume de solo explorado pelo sistema radicular de uma planta de citros. Revista Brasileira de Ciência do Solo, v. 29, n. 1, p. 1-10, 2005 .

EMPRESA BRASILEIRA DE PESQUISA AGROPECUÁRIA. Manual de métodos de análise de solo. 2. ed. Rio de Janeiro, 1997. 212 p.

EVETT, S. R. et al. Soil water sensing for water balance, ET and WUE. Agricultural Water Management, v. 104, p. $1-9,2012$.

FIGUEIREDO, J. V. de. Início da geração de escoamento superficial em uma bacia semiárida em Caatinga preservada. 2011. 83 f. Dissertação (Mestrado em Engenharia Agrícola) - Centro de Ciências Agrárias, Universidade Federal do Ceará, Fortaleza, 2011.

GAO, X. et al. Estimating spatial mean soil water contents of sloping jujube orchards using temporal stability. Agricultural Water Management, v. 102, n. 1, p. 66-73, 2011.

GREGO, C. R.; VIEIRA, S. R. Variabilidade espacial de propriedades físicas do solo em uma parcela experimental. Revista Brasileira de Ciência do Solo, v. 29, n. 2, p. 169177, 2005.

LANZANOVA, M. E. et al. Atributos físicos do solo em sistema de integração lavoura-pecuária sob plantio direto. Revista Brasileira de Ciência do Solo, v. 31, p. 1131-1140, 2007.

LI, Y. et al. On quantifying soil water deficit of a partially wetted root zone by the response of canopy or leaf conductance. Agricultural Water Management, v. 65, n. 1, p. 21-38, 2004.

LIMA NETO, I. E.; WIEGAND, M. C.; de ARAUJO, J. C. Sediment redistribution due to a dense reservoir network in a large semi-arid Brazilian basin. Hydrological Sciences Journal, v. 56, n. 2, p. 319-333, 2011.

MAILAPALLI, D. R. et al. Evaluation of time domain reflectometry (TDR) for estimating furrow infiltration. Irrigation Sciences, v. 26, n. 2, p. 161-168, 2008.

MEDEIROS, P. H. A.; ARAÚJO, J. C.; BRONSTERT, A. Interception measurements and assessment of Gash model performance for a tropical semi-arid region. Revista Ciência Agronômica, v. 40, n. 2, p. 165-174, 2009.

MEDEIROS, P. H. A. et al .Modelling spatio temporal patterns of sediment yield and connectivity at a semi-arid catchment with WASA-SED model. Hydrological Sciences Journal, v. 55, n. 4, p. 636-648, 2010. 
MIRANDA, F. R. de ; GONDIM, R. S.; COSTA, C. A. G. Evapotranspiration and crop coefficients for tabasco pepper (Capsicum frutescens L.). Agricultural Water Management, v. 82 , n. $1 / 2$, p. $237-246,2006$.

PARAJKA, J. et al. Assimilating scatterometer soil moisture data into conceptual hydrologic models at the regional scale. Hydrology and Earth System Sciences, v. 10, p. 353-368, 2006.

PENNA, D. et al. Hillslope scale soil moisture variability in a steep alpine terrain. Journal of Hydrology, v. 364, n. 3/4, p. 311-327, 2009.

PINHEIRO, E. A. R; COSTA, C. A. G.; ARAÚJO, J. C. de. Effective root depth of the Caatinga biome. Journal of Arid Environments, v. 89, p. 1-4, 2013.

QUINONES, H.; RUELLE, P. Operative Calibration Methodology of a TDR Sensor for Soil Moisture Monitoring under Irrigated Crops. Subsurface Sensing Technologies and Applications, v. 2, n. 1, p. 31-45, 2001.

RODRIGUES, J. O. et al. Modelos da Concentração Iônica em águas subterrâneas no Distrito de Irrigação Baixo Acaraú. Revista Ciência Agronômica, v. 38, n. 4, p. 360-365, 2007.

SANTOS, T. E. M.; SILVA, D. D.; MONTENEGRO, A. A. A. Temporal variability of soil water content under different surface conditions in the semiarid region of the Pernambuco State. Revista Brasileira de Ciência do Solo. v. 34, n. 5, p. 1733-1741, 2010.
SILVA, V. R. et al. Variabilidade espacial das características químicas do solo e profundidade do milho em um Argissolo Vermelho-Amarelo distrófico arênico. Revista Brasileira de Ciência do Solo. v. 27, p. 1013-1020, 2003.

SOUZA, Z. et al. Variabilidade especial de atributos físicos de um Latossolo Vermelho sob cultivo de cana-de-açúcar. Revista Brasileira de Engenharia Agrícola e Ambiental, v. 8, n. 1, p. 51-58, 2004.

TIMM, L. C. et al. Temporal variability of soil water storage evaluated for a coffee field. Soil Research, v. 49, n. 1, p. 77-86, 2011.

TIMM, L. C. et al. Sugarcane production evaluated by the state-space approach. Journal of Hydrology, v. 272, n. 1, p. 226-237, 2003.

VAN LIER, Q. de J.; DOURADO NETO, D.; METSELAAR, K. Modeling of transpiration reduction in Van Genuchten Mualem type soils. Water Resources Research, v. 45, n. 2, p. W02422, 2009.

WARRICK, A. W.; NIELSEN, D. R. Spatial variability of soil physical properties in the field. In: HILLEL, D. Applications of soil physics. San Diego: Academic Press, 1980. p. 319-345.

WILlmotT, C. J. On the validation of models. Physical Geography, v. 2, p. 184-194, 1981.

XAVIER, T. M. B. S.; XAVIER, A. F. S. Caracterização de períodos secos ou excessivamente chuvosos no estado do Ceará através da técnica dos quantis: 1964-1998. Revista Brasileira de Meteorologia, v. 14, n. 2, p. 63-78, 1999. 